\title{
ETHICS COMMITTEES FOR CORPORATE CULTURE OF SUSTAINABILITY
}

\author{
Francesca Gennari ${ }^{1}$
}

DOI: https://doi.org/10.31410/LIMEN.S.P.2019.25

\begin{abstract}
This theoretical paper considers the role of ethics committees in the promotion of business ethics and corporate culture of sustainability, and aims at contributing to the debate about the leadership role of board of directors as a real source of competition in global markets. Ethics committees within the boards can support leaders' commitment to corporate social responsibility, encourage stakeholder protection, reinforce the board's expertise about ethics and sustainability issues and safeguard the independence of decision-making processes in situations characterized by potential conflicts of interest. This paper could also have practical implications, encouraging policy makers to translate the good practices in managing corporate sustainability culture into actions and sending a message to investors sensitive to environmental, social, and governance (ESG) aspects. In fact, the establishment of ethics committees could be an indicator about the degree of maturity of corporate sustainability culture for investors and stakeholders in general.
\end{abstract}

Keywords: Business ethics, Corporate social responsibility, Board of directors.

\section{INTRODUCTION}

$\mathrm{T}$ he corporate scandals of recent decades highlight a scarce ethical orientation by companies, together with the essential inability to manage relations with broad stakeholder categories. In fact, while some failures were the result of fraudulent accounting and other illegal practices, many of the same companies exhibited real corporate governance risks such as conflicts of interest, inexperienced directors, excessive directors' remuneration, or the unequal share of voting rights (Anderson \& Orsagh, 2004; Arjoon, 2005; Salvioni, Gennari, \& Astori, 2015).

Corporate governance standards, starting from the Sarbanes Oxley Act, focus, inter alia, on board structure, with the aim of strengthening the safeguarding of minority shareholders and other stakeholders. Corporate governance systems, according to the agency theory (Fama, 1980; Jensen \& Meckling, 1976; Ross, 1973), are based on a proxy tie between shareholders and corporate governance bodies (OECD,1999). The board is empowered by the shareholders to define and realize goals and strategies that safeguard their interests, and the board structure and composition is one of the mechanisms to mitigate the so-called agency conflicts (Bathala \& Rao, 1995; Daily, Dalton, \& Cannella, 2003; Eisenhardt, 1989; Jensen, 2000; Weisbach, 1988; Zahra \& Pearce, 1989).

The shareholder view (Friedman, 1962) has emphasised for a long time the dominance of economic responsibility in satisfying the financial expectations of shareholders. This often means excessive stress on short-term results for boards of corporate governance systems characterized by wide dispersed ownership (so-called outsider systems), with the aim of obtaining positive judgements from the financial market and reconfirming their position. This attention to shortterm performance could be the cause of unethical conduct by boards oriented towards personal or relevant shareholders' interests to the detriment of other stakeholder categories. In the same

Department of Economics and Management, University of Brescia, via S. Faustino 74/b, 25122 Brescia, Italy 
way, unethical and fraudulent action in corporate governance systems with concentrated and stable shareholding (so-called insider systems), are often caused by the will of majority shareholders, usually members of the board, to focus on economic performance over time, increasing the company's value in terms of personal assets.

Stressing the economic dimension in corporate goals and actions can imply the board structure is not an effective controlling mechanism for managing agency conflicts and avoiding scandals. Byrne (2002) noted that in the post-Enron and post-bubble world, the realization that many companies played fast and loose, allowing performance disconnected from meaningful corporate values, was leading to a re-evaluation of corporate goals, values, and purpose. The economic and financial disasters led to a new corporate model in which corporate culture puts greater emphasis on ethics, integrity and trust (Arjoon, 2005).

Such changes include the triumph of Corporate Social Responsibility (CSR) principles and sustainability values (Gladwin, Kennelly, \& Krause, 1995; Elkington, 1998), which, together with the enhancement of stakeholder perspective (Freeman,1984; Freeman, 1994; Harrison, Bosse, \& Phillips, 2010; Freeman \& Dmytriyev, 2017), emphasise the concept of global corporate responsibility. According to this approach, corporate goals defined by the boards should involve clear awareness of the responsibilities towards different stakeholders, adopting methods and tools of governance aimed at improving economic, social, and green/eco-friendly performance.

To this regard, the effectiveness of corporate governance depends on the members of boards that should be able to manage the equilibrium between short-term and long-term chances of company survival, positively valued by the stock market. Board structure has been extensively studied as a factor determining a higher or lower corporate orientation towards social responsibility and sustainability (Driscoll, 2001; Zhang, Zhu, \& Ding, 2013) being capable of managing the complexity along the so-called 'triple bottom line', and the establishment of dedicated committees within the board can be a further guarantee that stakeholders' interests are considered in a balanced way, preventing and managing potential conflicts of interests among them and with managers. The establishment of board committees encourages stakeholder protection, reinforces the board's expertise and commitment and safeguards the independence of decision-making processes in awkward situations (OECD, 2015). National binding laws (e.g. Sox, 2002; the Swedish Companies Act, 2006; Portuguese Law 76-A, 2006), international institutions (e.g. the OECD, the United Nations with Global Compact initiative, the ICGN, the European Commission) and national market regulators have governed board committees, with particular focus on audit, nomination and remuneration committees because of the high risks of conflicts of interest characterizing these areas. Clearly, the management of conflicts of interests by the aforementioned committees assumes ethical implications, having positive effects on relations with stakeholders and long-term sound corporate development.

Globalization and the emergence of the concepts of corporate social responsibility and sustainable development have undoubtedly underlined the need for the institutionalization of business ethics. This has gradually led to the diffusion of certain ethics committees, rarely as a legal requirement and more frequently as a recommended self-discipline practice or autonomous corporate initiative.

Sharing the concept that companies need leadership commitment to become sustainable (Eccles, Miller, \& Serafeim, 2012), we first focus on the influence of board structure on corporate social performance (CSP). We acknowledge that the board affects corporate performance through its 
goals and decisions, but we share the limitations of input-output methods that attempt to identify a direct and measurable relation between board structure and the social dimension of corporate performance. For this reason, we suggest a different perspective, focusing on the board structure for the promotion of a corporate culture inspired by CSR.

Then we discuss the ethics committees. Scholars and regulators have paid very little attention to such committees but, in this void, companies are submitting themselves to self-regulation to shape actively their future and to create their own conditions for success and sustainable development in global markets. These corporate efforts can be considered voluntary investments in the governance decision-making process, which means investments in sustainable and longterm success (Lin-Hi \& Blumberg, 2011). Finally, we make some considerations. Globalization is gradually changing the traditional performance indicators; monitoring committee boards can provide important information to investors and market regulators on how companies are moving towards ethics and sustainability.

\section{BOARD STRUCTURE AND CORPORATE CULTURE}

Ongoing debates about the relations and overlapping between corporate governance and CSR have become a priority for companies and policy makers. Since the board is responsible for the corporate goals and internal processes promoting the achievement of these goals in the organisation, scholars, international organisations, regulators and politicians have focused on the relationship between board structure and sound governance, considering in particular the presence of non-executive and independent members and the separation of CEO and Chairman position as a means to guarantee an objective judgement capacity for the protection of the interests of minority shareholders and other stakeholders.

The most popular approach in the study of board effectiveness has been to relate board composition to various measures of firm performance (Bathala \& Rao, 1995; Rao \& Tilt, 2016): if boards are capable of controlling agency problems and enhancing value for stakeholders, this should result in better corporate performance, in the short as well as the long term. The measurement of a board's commitment to social responsibility includes environmental and social output, in addition to financial considerations (Haugh \& Talwar, 2010; Prahalad \& Hammond, 2002).

Some scholars have found positive relationships between the number of outside, independent directors and Corporate Social Performance (CSP), in terms of employee orientation (Wang \& Dewhirst, 1992), philanthropic activities (Ibrahim \& Angelidis, 1995; Ibrahim, Howard, \& Angelidis, 2003), environmental standards and product quality (Johnson \& Greening, 1999). Vice versa, Surroca and Tribò (2008) and Bear, Rahman, and Post (2010) affirm that diversity of directors' resources (insider directors with expertise in corporate strategies and operations and outsider directors with expertise in monitoring and advising) is not directly associated with social ratings. Also, Zhang et al. (2013) do not offer significant results to support the positive effects of the number of outside directors on a firm's reputation in the industry. Other scholars show neutral findings (McKendall, Samchez, \& Sicilian, 1999; Wang \& Dewhirst, 1992).

The lack of clear evidence of a direct relationship between board structure and CSP is not entirely surprising; in this regard, other scholars have considered corporate performance to be a function of a number of other factors (Bathala \& Rao, 1995). This research approach, called the input-output model (Pettigrew, 1992), attempts to link the board structure (input) directly to company perfor- 
mance (output), ignoring the processes involved in the board's performance of its tasks (Dalton, Daily, Johnson, Ellstrand, 1999; Forbes \& Milliken, 1999; Gabrielsson \& Huse, 2004; Golden \& Zajac, 2001; Macus, 2008). A number of factors, primarily determined by the structure of ownership, the characteristics of corporate governance systems, the structure and values that dominate the board and the ability to transfer them to the organisation, heavily influence business behaviour. The limitations of the input-output model lead us to change perspective, or at least to consider the input-output model together with an additional perspective, linking board structure with its potential power to promote a corporate culture inspired by social responsibility and sustainability. Whilst the damaging consequences of a negative (unethical) corporate culture are widely discussed, there are not many discussions focused on culture as a driver of sustainability (BlackSun, 2017).

Corporate culture, defined as ways of thinking, values and beliefs that influence people's behaviour (Green, 1988; Kerr and Slocum, 2005; Kluckhohn \& Strodtbeck, 1973) can be considered the real drive behind a board's processes. Authors have argued that corporate culture, instead of management technique, is the key to corporate excellence (Deal \& Kennedy, 1982; Peters \& Waterman, 1982). It is corporate culture, rather than strategy, that is the key to understanding an organisation's success. If the culture is right, then the right strategy will emerge or will be implemented; in this sense, culture is one of the key immaterial factors of success (Brondoni, 2010; Green, 1988;). Companies themselves declare that culture is one of the most important immaterial factors of value creation (BlackSun, 2017).

Changes in corporate culture start at the leader level and leadership commitment allows companies to become sustainable (Eccles, Kathleen, \& Serafeim, 2012). According to Eccles et al. (2012), this cultural shift is not immediate, but the path to a sustainable company considers two ongoing stages: the first involves reframing the company's identity through leadership commitment and external engagement; the second involves codifying the new identity through employee engagement and mechanism of execution. For Marlow, Beale and Burn (2010), the corporate pathway to sustainability consists of gradual steps from compliance, focusing on the reduction of risk, through the integration of sustainability into business strategy, to full commitment to sustainability, with the aim of improving the overall wellbeing of the company, community and environment.

According to these views, the presence of dedicated directors within the board can be considered a visible manifestation (Schein, 1984) of the culture of sustainability, a tool to promote and monitor the spread of ethics and the sharing of the triple bottom line in all the behaviours of an organisation. In more complex organisations, effective liability management may also be supported by the adoption of a plan of ethical corporate culture, with the appointment of an Ethics Officer (EO) or a Chief Sustainability Officer (CSO), and the creation of a Social and Ethics Committee (S\&EC).

\section{ETHICS COMMITTEES. A LITERATURE REVIEW}

All over the world, corporate governance bodies foresee the establishment of internal committees, usually made up of independent members. The most widely used committees are those of risk management and audit, remuneration and nomination. By affirming the principles of social responsibility and sustainability, companies more conscious of the importance of the spread of a culture of ethics have also begun to introduce committees for this purpose.

The increase in number of ethics committees is an indication of the board's desire to promote ethically accountable behaviours and implementing initiatives to increase the awareness and 
importance of corporate social responsibility in all players of the organisation (Gennari and Salvioni, 2019). Therefore, the existence of social and ethics committees is expected to have a positive impact on corporate governance and it is recommended by numerous researchers (Sims, 1991; Singh, 2011; Weber, 1981; Wood, 2002).

The main purpose of the social and ethics committee is to review and recommend to the management and board of directors objectives, policies and procedures that serve the company's interest to maintain a company committed to high standards of ethics and integrity, legal compliance and integrated corporate responsibility. There are good reasons for the establishment of an ethics committee within a board (Purcell, 1982). First, the committee gives emphasis and visibility to the structuring of ethical issues, as a significant instrument holding management accountable for its administration of the company. Such a committee can be a significant aid in diffusing CSR culture throughout the organisation and obtaining corporate legitimacy within the community. In fact, this committee should ensure the establishment and formalization of policies on corporate ethics and codes of ethics provide the actual practices and documents that are to be monitored, extended or revised over time. Furthermore, ethics committee can contribute to the board's decision-making processes, according to a long-term value creation approach.

The typical activities carried out by ethics committees are: planning an ethics program that usually includes the proposal and updating of the Code of Ethics, the review of results, the assessment of resource allocation, the monitoring of company activities with regard to social and economic development, good corporate citizenship, environment, health and public safety, stakeholder relationships (Deloitte \& Touche, 2014; Felo, 2001). In addition to than these tasks, considering that due diligence towards social responsibility can create, in the short term, potential conflict between the shareholders' immediate profit expectations and the long-term creation of value, the presence of ethics committees helps to solve such trade-offs. Where trade-offs exist, the CSR approach recommends prioritizing the long-term sustainable creation of value as fundamental to a company's future life and success, promoting the creation of stakeholder value (shareholders included) over time.

Well-structured ethics committees (also referred to as conduct, corporate responsibility, CSR, sustainability committees and so on) not only serve as a critical coordinating function, but they can also steer a CSR strategy to becoming a competitive advantage, acting as a mediator among possibly conflicting interests. Furthermore, in this case, the board's commitment to value creation in the long-term is more visible to financial markets and external stakeholders than when the responsibility for social issues is assigned to other committees (audit, remuneration) or to the board as a whole.

The importance of ethics committees increases in the light of the UN 2030 Agenda for Sustainable Development, with its 17 goals to be reached in the coming years: committee members should promote the consideration of these goals in the board discussions about corporate objectives and strategies, focusing on a fair balance between opportunities and risks. In fact, sustainability risk management has also become a crucial issue, as corporate strategy now must ensure that sustainability policies and impacts do not deflect the achievement of primary business objectives (Salvioni et al., 2016; Burke, Hoitash \& Hoitash, 2017; COSO, 2017; Gennari, 2019).

Nevertheless, little attention has been paid to ethics committees until recently, and the majority of interventions are in the area of self-regulation. Some market regulators (stock exchanges supervisors, government commissions, associations of particular categories of stakeholders, etc.) promote the formation of these committees by means of self-discipline codes that often follow 
the 'comply or explain' principle, which means that companies have to justify non-compliance with the code when they fail to meet certain requirements. There are exceptions, such as South Africa and India, where the establishment of such a committee is mandatory by law.

Ethics committees have been debated in literature in the past, with greater focus in the last twenty years. Many studies have attempted to find a direct association between the existence of such committees and performance outcome (Baxter, Bedard, Hoitash, \& Yezegel, 2013; Beasley, Berrone \& Gomez-Mejia 2009; Conyon \& Peck 1998; Klein 1998; Rodrigue, Magnan, \& Cho, 2013; Uzun, Szewczyk, \& Varma, 2004; Walls, Berrone, \& Phan 2012), but this is not our intended perspective.

The increasing presence of ethics committees is proved by some studies: Spitzeck (2009) indicated that there has been an increasing trend in forming corporate responsibility committees in the CSR Index (CRI) in the UK; Eccles, Iannou, and Serafeim (2014) found that US companies with high sustainability adopt such a committee; Burke, Hoitash, and Hoitash (2017) found that sustainability committees in public companies became increasingly prevalent over the period 2003-2013. In addition, practitioner publications (Calvert Asset Management \& The Corporate Library, 2010; Institute of Business Ethics, 2016) have reported the increasing presence of sustainability committees. However, these results are not sufficiently comforting: research by Kiron et al. (2015) shows that only $22 \%$ of managers perceive that their boards provide substantial oversight on sustainability issues, confirming the results of the UNEP Integrated Governance report (2014) of 2011 Bloomberg corporate data on 60,000 businesses.

For Miller and Serafeim (2014), the way the authority and responsibilities for sustainability differ across organisations indicates the stages of sustainability commitment. During the compliance stage, the point when most companies first engage with sustainability, companies do not have a formal chief sustainability position and those primarily responsible for sustainability have a wide range of responsibilities, but are not positioned at high levels of authority. The activities are neither strategic nor centralized. During the next stage, called the efficiency stage, companies begin to focus on how they can respond to stakeholder pressures, legitimizing sustainability by means of internal stakeholder engagement. The ultimate responsibility for sustainability is assigned to the Chief Executive Officer (CEO) who works in partnership with the new Chief Sustainability Officer (CSO) to develop strategies and educate the organisation to sustainability. The last stage is the innovation stage. The strategies become market-driven and the ultimate responsibility for sustainability shifts from the CEO to the CSO accordingly; the incidence of the board having a special committee on sustainability increases dramatically.

Gennari and Salvioni (2019), analysing more than 22,000 boards of European companies in 20002016 found that the number of companies with social and ethics committees gradually increases from $2.46 \%$ to $6.70 \%$ and the committees' names developed. In particular, the word 'sustainability' becomes the most recurrent word in the committee names from 2010. Up until then, the terms ethics/ethical prevail, examining the big business scandals such as Enron, WorldCom, Ahold, Parmalat and the financial crisis that began in early 2000 and the consequent need for companies to recover the confidence of stakeholders. The concept of sustainability starts to spread at the end of the first decade of the 2000s, also in consideration of the great emphasis first placed first on concepts such as business ethics and CSR, and then on the stakeholder model, sustainability and the triple bottom line. In any case, the word ethics or ethical continues to be used very frequently, showing a correspondence between corporate ethical behaviour and corporate legitimacy to operate. It is also worth 
pointing out that, as a first stage, businesses tend to separate the aspects of social and environmental responsibility and link ethics predominantly to compliance. Subsequently, a broader concept of social responsibility has emerged, understood as the liability of companies for their impact on society, where compliance and the internal diffusion of ethical culture are the relative prerequisites. Furthermore, the Authors, according with the institutional theory, examined the relation between external country-variables and the establishment of CSR committees confirming that the only variable impacting on such committees is the mandatory non-financial disclosure ex Directive 2014/95/EU.

\section{DISCUSSION}

Starting with the existing literature, we aim to contribute to the debate on the importance of ethics committees as tools to promote the continuous commitment of the board to ethical and sustainability issues. The presence of special committees is of dual advantage: externally, it can serve as an important message to stakeholders about the management of social responsibility; internally, it expresses the progress of sustainability culture into corporate levels. Corporate culture should be considered a critical, primary intangible factor for the long-term creation of value and for competitive advantage (Salvioni, Franzoni \& Gennari, 2016); for this reason, it should be formalized, monitored and managed. This vision combines the traditional focus of corporate responsibility on the measurement of external impact with the focus on what drives behaviours within the organisation. Furthermore, committees can play a useful role in identifying, on behalf of the board, problems and patterns of behaviour that may indicate risk (Institute of Business Ethics, 2016).

Based on these considerations, we think that our paper can contribute to keep alive the international debate on corporate ethics and the role of boards committees for a sound and sustainable corporate governance. In general, the cultural issue should be debated further. When the culture becomes a critical intangible factor of competitive success in global markets, ethics committees should provide key performance indicators to measure and monitor corporate culture, together with socio-environmental indicators expressing the multidimensionality of performance across the triple bottom line. In other words, committee tasks should go beyond the recommendation of sustainable strategies to the board; ethics committees should engage dedicated directors to support dialogue between the board and the figures responsible for internal control systems aimed at spreading the board's goals within the organisation. The contribution of ethics committees extends to external relations with key stakeholders, since such committees can design, together with the Investor Relations function, the information architecture to comply with the change in the mandatory disclosure of the different EU countries deriving from the 2014/95/EU Directive on non-financial and diversity information.

We suggest integrating the traditional literature review about the effects of CSR on company performance with a perspective that focuses on creating and strengthening a strong corporate social culture. This culture of sustainability and the creation of shared value in the long-term, thanks to risk reduction and exploitation of opportunities by means of continuous and bidirectional relations with stakeholders (stakeholder engagement), is an intangible and unique driver for success in global markets. In fact, global markets have replaced the traditional markets of $20^{\text {th }}$ century industrial systems, introducing new development models, relations between companies and institutions and market relations. In this environment, companies develop complex models of competitive interaction and long-term corporate success is conditioned more by the level of sophistication of the intangible assets than corporate culture (Brondoni, 2010). 
This debate could also have practical implications, encouraging policy makers to translate good practices in managing corporate sustainability culture into actions. The regulators can be passive and let sustainability emerge as the result of market dynamics. Alternatively, regulators can choose to introduce mandatory (to stimulate fast cultural change) or self-disciplinary measures, promoting continuous dialogue among involved actors. In this sense, a significant boost could come from the UN Agenda 2030 that defines Sustainable Development Goals (SDGs) and explicitly sustains joint action among the institutional, civil and business world. Other measures could be the introduction of incentives for companies to encourage the adoption of certain behaviours, the proposal of voluntary guidelines with reference to international standards, the transfer of regulatory powers to self-regulating authorities, such as stock exchanges. All these rules should promote cultural changes when they are coherent with the national historical, social and economic background, as well as the transposition of international principles. The respect of laws and recommendations cannot provide the expected results when it is perceived by companies to be mere and formal compliance activity. The value of compliance should be embedded into the corporate culture, as a shared principle that guides the behaviour of the entire organisation and constitutes the basis for managing any type of risk related to global corporate responsibility.

Finally, we would like to send a message to investors in consideration of both sustainability performances and indicators. The corporate structure, in terms of board committees, can be one of these indicators, providing information on the leadership commitment to including CSR in the corporate goals. Where there are trade-offs among the interests of different stakeholders, the CSR approach recommends prioritizing the long-term sustainable creation of value as fundamental to the company's future life and success. The foundation of ethics committees and their composition could be a clear indicator of the degree of maturity of the sustainability culture of a company for investors and stakeholders in general.

The story of social and ethics committees is a story about how CSR issues should be expressed and managed in the interest of stakeholders. The task for corporate governance bodies and organisations is not easy and has short-term results, but the direction of travel seems right.

\section{REFERENCES}

Anderson, G., \& Orsagh, M. 2004. The Corporate Governance Risk. Electric Perspectives, 29(1): 68 .

Arjoon, S. 2005. Corporate Governance: An Ethical Perspective. Journal of Business Ethics, 61(4): 343-352.

Bathala, C. T., \& Rao, R. P. 1995. The Determinants of Board Composition: An Agency Theory Perspective. Managerial and Decision Economics, 16: 59-69.

Baxter, R., Bedard, J. C., Hoitash, R., \& Yezegel, A. 2013. Enterprise risk management program quality: Determinants, value relevance, and the financial crisis. Contemporary Accounting Research, 30, 1264-1295.

Bear, S., Rahman, N., \& Post, C. 2010. The Impact of Board Diversity and Gender Composition on Corporate Social Responsibility and Firm Reputation. Journal of Business Ethics, 97(2): 207-221.

Beasley, M. S., Carcello, J. V., Hermanson, D. R., \& Lapides, P. D. 2000. Fraudulent financial reporting: Consideration of industry traits and corporate governance mechanisms. Accounting Horizons, 14, 441-454.

Black Sun. 2017. On the Culture Trail. Black Sun Plc Report. 
Brondoni, S. M. 2010. Intangibles, Global Networks \& Corporate Social Responsibility. Symphonya. Emerging Issues in Management, 2: 6-24. http://dx.doi.org/10.4468/2010.2.02brondoni

Burke, J. J., Hoitash, R., \& Hoitash, U. 2017. The Heterogeneity of Board-Level Sustainability Committees and Corporate Social Performance. Journal of Business Ethics, Forthcoming.

Byrne, J. 2002. How to Fix Corporate Governance. Business Week, 6: 69-78

Calvert Asset management \& The Corporate Library, 2010. Board Oversight of Environmental and Social Issues: An Analysis of Current North American Practice. Available on line.

Conyon, M., \& Peck, S. I. 1998. Board control, remuneration committees, and top management compensation. Academy of Management Journal, 41, 146-157.

COSO - Committee of Sponsoring Organizations of the Treadway Commission, 2017. Enterprise Risk Management Integrating with Strategy and Performance. COSO Publishing.

Daily, C. M., Dalton, D. R., \& Cannella A. A. 2003. Corporate governance: Decades of dialogue and data. Academy of Management Review, 28(3): 371-382.

Dalton, D. R., Daily, C. M., Johnson, J. L., \& Ellstrand, A. E. 1999. Number of Directors and Financial Performance: A Meta- Analysis. Academy of Management Journal, 42: 674-686.

Deal, T. E., \& Kennedy, A. A. 1982. Corporate Culture: The Rites and Rituals of Corporate Life. Reading. MA: Addison-Weslev.

Deloitte \& Touche 2014. The Social and Ethics Committee and the management of the Ethics Performance of the Company. Johannesburg: Deloitte \& Touche.

Driscoll, D. (2001). Ethics and Corporate Governance: Lessons Learned from a Financial Services Model. Business Ethics Quarterly, 11(1), 145-158.

Eccles, R. G., Iannou, I., \& Serafeim, G. 2014. The Impact of Corporate Sustainability on Organizational Processes and Performance. Management Science, 6: 2835-2857.

Eccles, R., Kathleen, M. P., \& Serafeim G. 2012. How to become a sustainable company, MIT Sloan Management Review, 53(4), 43-50.

Eccles, R. G., Miller P. K., \& Serafeim, G. 2012. How to Become a Sustainable Company. MIT Sloan Management Review, 53(4): 42-51.

Eisenhardt, K.M. 1989. Agency Theory: An Assessment and Review. Academy of Management Review, 14(1): 57-74.

Elkington, J. 1998. Cannibals with forks: The triple bottom line of $21^{\text {st }}$ century business. Canada: New Society.

Fama, E. F. 1980. Agency Problems and the Theory of the Firm. The Journal of Political Economy, 88(2): 288-307.

Felo, A. J. 2001. Ethics Programs, Board Involvement, and Potential Conflicts of Interest in Corporate Governance, Journal of Business Ethics, 32(3), 205-218.

Forbes, D. R, \& Milliken, F. J. 1999. Cognition and Corporate Governance: Understanding Boards of Directors as Strategic Decision-Making Groups. Academy of Management Review, 24: 489-505.

Freeman, R. E. 1984. Strategic management: A stakeholder approach. Boston, MA: Pitman.

Freeman, R. E. 1994. The Politics of Stakeholder Theory: Some Future Directions. Business Ethics Quarterly, 4(4): 409-421.

Freeman, R. E., \& Dmytriyev, S. 2017. Corporate Social Responsibility and Stakeholder Theory: Learning From Each Other. Symphonya. Emerging Issues in Management,1. http:// dx.doi.org/10.4468/2017.1.02freeman.dmytriyev

Friedman, M. 1962. Capitalism and Freedom. Chicago: University of Chicago Press.

Gabrielsson, J., \& Huse, M. 2004. Context, Behavior, and Evolution: Challenges in Research on Boards and Governance. International Studies of Management and Organization, 34(2): 11-36. 
Gennari, F, \& Salvioni, D. M. 2019. CSR committees on boards: the impact of the external country level factors. Journal of Management and Governance, 23(3): 759-785. https://doi. org/10.1007/s10997-018-9442-8

Gennari, F. 2019. How to Lead the Board of Directors to a Sustainable Development of Business with the CSR Committees. Sustainability, 11(24): 6987. https://doi.org/10.3390/su11246987

Gladwin, T. N., Kennelly, J. J., \& Krause, T. S. 1995. Shifting paradigms for sustainable development: Implications for management theory and research. Academy of Management Review, 20: 874-907.

Golden, B.R., \& Zajac, E. J. 2001. When Will Boards Influence Strategy? Inclination x Power = Strategic Change. Strategic Management Journal, 22: 1087-1111.

Green, S. 1988. Understanding Corporate Culture and Its Relation to Strategy. International Studies of Management \& Organization, 18(2): 6-28.

Harrison, J. S., Bosse, D. A., \& Phillips, R. A. 2010. Managing for stakeholders, stakeholder utility functions, and competitive advantage. Strategic Management Journal, 31: 58-74.

Haugh, H. M., \& Talwar, A. 2010. How Do Corporations Embed Sustainability Across the Organization? Academy of Management Learning \& Education, 9(3): 384-396.

Ibrahim, N. A., \& Angelidis, J. P. 1994. Effect of board members' gender on corporate social responsiveness orientation. Journal of Applied Business Research, 10(1), 35-41.

Ibrahim, N. A., Howard, D. P., \& Angelidis, J. P. 2003. Board members in the service industry: An empirical examination of the relationship between corporate social responsibility orientation and directorial type. Journal of Business Ethics, 47(4): 393-401.

Institute of Business Ethics, 2016. Culture by Committee: the pros and cons. London: Institute of Business Ethics.

Jensen, M. C. 2000. A Theory of the Firm: Governance, Residual Claims and Organizational Forms. Harvard: Harvard University Press.

Jensen, M. C., \& Meckling W. 1976. Theory of the firm: Managerial behaviour, agency costs and ownership structure. Journal of Financial Economics, 3(4): 305-360.

Johnson, R. A., \& Greening, D. W. 1999. The effects of corporate governance and institutional ownership types on corporate social performance. Academy of Management Journal, 42(5): 564-576.

Kerr, J., \& Slocum, J. W. 2005. Managing Corporate Culture through Reward Systems. The Academy of Management Executives, 19(4): 130-138.

Kluckhohn, F. R., \& Strodtbeck, B. L. 1973. Variations in Value Orientations. Westport, CT: Greenwood.

Lin-Hi, N., \& Blumberg, I. 2011. The relationship between corporate governance, global governance, and sustainable profits: lessons learned from BP. Corporate Governance: The international journal of business in society, 11(5): 571-584.

Macus, M. 2008. Board Capability. An Interactions Perspective on Boards of Directors and Firm Performance. International Studies of Management \& Organisation, 38(3): 98-116.

Marlow, D., Beale, D. J., \& Burn, S. 2010. Linking asset management with sustainability: Views from the Australian sector. American Water Works Association, 102(1): 56-67.

McKendall, M., Samchez, C., \& Sicilian, P. 1999. Corporate governance and corporate illegality: The effects of board structure on environmental violations. International Journal of Organizational Analysis, 7(3), 201:223.

Miller, K., \& Serafeim, G. (Eds) 2014. Chief Sustainability Officers: Who Are They and What Do They Do? Leading Sustainable Change. Oxford: Oxford University Press.

Pettigrew, A. 1992. On Studying Managerial Elites. Strategic Management Journal, 13: 163182. 
Prahalad, C. K., \& Hammond, A. 2002. Serving the World's Poor, Profitably. Harvard Business Review, September.

Purcell, T. V. 1982. The Ethics of Corporate Governance. Review of Social Economy, 40 (3): 360-370.

Rao, K., \& Tilt, C. 2016. Board Composition and Corporate Social Responsibility: The Role of Diversity, Gender, Strategy and Decision Making. Journal of Business Ethics, 138(2): 327-347.

Rodrigue, M., Magnan, M., \& Cho, C. H. 2013. Is environmental governance substantive or symbolic? An empirical investigation. Journal of Business Ethics, 114, 107-129.

Ross, S. 1973. The Economic Theory of Agency: The Principal's Problem. American Economic Review, 63(2): 134-139.

Salvioni D. M., Franzoni S., \& Gennari F. 2016. Corporate Governance Systems and Sustainability: CSR as a Factor of Convergence between Outsider and Insider Systems. Corporate ownership \& control, 14: 139-150.

Salvioni, D. M., Gennari, F., \& Astori, R. 2015. Corporate Responsibility and Ethical Culture in Pharmaceutical Industry. Journal of Business \& Economic Policy, 2(2): 62-84.

Salvioni, D. M., Gennari, F., \& Bosetti L. 2016. Sustainability and Convergence: The Future of Corporate Governance Systems? Sustainability, 8(11): 1203. https://doi.org/10.3390/ su8111203

Schein, E. H. 1984. Coming to a New Awareness of Organizational Culture, MIT Sloan Management Review, 25(2): 3-16.

Sims, R. R. 1991. The institutionalization of organizational ethics. Journal of Business Ethics, 10(7): 493-506.

Singh, J. 2011. Determinants of the Effectiveness of Corporate Codes of Ethics: An Empirical Study. Journal of Business Ethics, 101(3): 385-395.

Spitzeck, H. 2009. The development of governance structures for corporate responsibility. Corporate Governance, 9(4): 495-505.

Surroca, J., \& Tribò, J. A. 2008. Managerial Entrenchment and Corporate Social Performance. Journal of Business Finance and Accounting, 35(5-6): 748-760.

Uzun, H., Szewczyk, S. H., \& Varma, R. 2004. Board composition and corporate fraud. Financial Analysts Journal, 60, 33-43.

Walls, J. L., Berrone, P., \& Phan, P. H. 2012. Corporate governance and environmental performance: Is there really a link? Strategic Management Journal, 33, 885-913.

Wang, J. \& Dewhirst, H. D. 1992. Boards of directors and stakeholder orientation. Journal of Business Ethics, 11(2): 115-123.

Weber, J. 1981. Institutionalizing Ethics into the Corporation. MSU Business Topics, Spring: 47-51.

Weisbach, S. M. 1988. Outside directors and CEO turnover. Journal of Financial Economics, 20: 431-460.

Wood, G. 2002. A Partnership Model of Corporate Ethics. Journal of Business Ethics, 40(1): 61-73.

Zahra, S. A., \& Pearce, J. A. 1989. Boards of directors and corporate financial performance: a re- view and integrative model. Journal of Management, 15: 291-334.

Zhang, J. Q., Zhu, H., \& Ding, H. 2013. Board Composition and Corporate Social Responsibility: An Empirical Investigation in the Post Sarbanes-Oxley Era. Journal of Business Ethics, 114(3): 381-392. 